\title{
Spatio-temporal variation of throughfall in a hyrcanian plain forest stand in Northern Iran
}

\author{
Saleh Yousefi ${ }^{1}$, Seyed Hamidreza Sadeghi ${ }^{2 *}$, Somayeh Mirzaee ${ }^{3}$, Martine van der Ploeg ${ }^{4}$, \\ Saskia Keesstra ${ }^{4}$, Artemi Cerdà ${ }^{5}$ \\ ${ }^{1}$ Department of Watershed Management, Faculty of Natural Resources, Tarbiat Modares University, Tehran, Iran. \\ E-mail: saleh.yousefi@modares.ac.ir \\ ${ }^{2}$ Department of Watershed Management Engineering, Faculty of Natural Resources, Tarbiat Modares University, Noor 46417-76489, Iran. \\ ${ }^{3}$ Department of Watershed Management, Faculty of Natural Resources, Lorestan University, Khoramabad, Iran. \\ E-mail: s.mirzaee90@yahoo.com \\ ${ }^{4}$ Soil Physics and Land Management Group, Wageningen University, Droevendaalsesteeg 4, 6708PB Wageningen, The Netherlands. \\ E-mails: martine.vanderploeg@wur.nl, saskia.keesstra@wur.nl \\ ${ }^{5}$ Soil Erosion and Degradation Research Group, Department of Geography, University of Valencia, Valencia, Spain. \\ E-mail: artemio.cerda@uv.es \\ * Corresponding author. Tel.: +98 11 44553102. Fax: +98 11 44553909. E-mail: sadeghi@modares.ac.ir
}

\begin{abstract}
Elucidating segregation of precipitation in different components in forest stands is important for proper forest ecosystems management. However, there is a lack of information on important rainfall components viz. throughfall, interception and stemflow in forest watersheds particularly in developing countries. We therefore investigated the spatiotemporal variation of important component of throughfall for a forest stand in a Hyrcanian plain forest in Noor City, northern Iran. The study area contained five species of Quercus castaneifolia, Carpinus betulus, Populus caspica and Parrotia persica. The research was conducted from July 2013 to July 2014 using a systematic sampling method. Ninetysix throughfall collectors were installed in a $3.5 \mathrm{~m} \times 3.5 \mathrm{~m}$ grid cells. The canopy covers during the growing/leaf-on (i.e., from May to November) and non-growing/leaf-off (i.e., from December to March) seasons were approximately $41 \%$ and $81 \%$, respectively. The mean cumulative throughfall during the study period was $623 \pm 31 \mathrm{~mm}$. The average throughfall $(T F)$ as $\%$ of rainfall $(T F P R)$ during leaf-on and leaf-off periods were calculated $56 \pm 14 \%$ and $77 \pm 10 \%$, respectively. $T F$ was significantly $\left(R^{2}=0.97, p=0.00006\right)$ correlated with gross precipitation. Percent of canopy cover was not correlated with $T F$ except when gross precipitation was $<30 \mathrm{~mm}$. A comparison between leaf-off and leaf-on conditions indicated a significantly higher $T F P R$ and corresponding hotspots during leaf-on period. $T F P R$ also differed between seasons with a maximum amount in winter $(82 \%)$. The results of the study can be effectively used by forest watershed managers for better perception of hydrological behavior of the Hyrcanian forest in the north of Iran under different silvicultural circumstances leading to getting better ecosystem services.
\end{abstract}

Keywords: Caspian Hyrcanian Forest; Deciduous forest; Forest hydrology; Interception storage; Precipitation loss.

\section{INTRODUCTION}

To understand the hydrological cycle and ecosystem services, it is necessary to quantify the role of vegetation in partitioning rainfall resulting in water balance at pedon, slope and watershed scale, and correspondingly the runoff, sediment, nutrients, contaminants and even biota redistribution (Buendia et al., 2016; Cao et al., 2008; Celentano et al., 2016; Cox et al., 2006; Davudirad et al., 2016; Gabarrón-Galeote et al., 2013; García-Fayos et al., 2010; Hosseini et al., 2016; Keesstra et al., 2009; Keesstra et al., 2012; Lal, 1997; Novara et al., 2013; Pereira et al., 2013; Sadeghi et al., 2015; Yousefi et al., 2016; Vega et al., 2005). Improving our understanding about rainfall partitioning in forests ecosystems is very important for studies that focus on forest hydrology to better management and decision making on this vital ecosystems (Ajami et al., 2011; Brecciaroli et al., 2012; Davudirad et al., 2015; Dohnal et al., 2014; Frot et al., 2007; Holko et al., 2009; Xu et al., 2014). Such eco-hydrological studies lead to a proper hydrological balance analysis and therefore have been well considered in forest hydrology studies during last few decades (Adriaenssens et al., 2012; Bosch and Hewlett, 1982; Carlyle-Moses, 2004; Devlaeminck et al., 2005; Gurav et al., 2012; Marin et al., 2000; Llorens and Domingo, 2007; Mitchell et al., 1986;
Molina and Campo, 2012; Nanko et al., 2006; Park and Cameron, 2008; Rahmani et al., 2011; Shachnovich et al., 2008; Tcherepanov et al., 2005; Xu et al., 2014).

Net rainfall reaches the forest floor through the tree canopy by throughfall and stem flow (Aikawa et al., 2006; Deng et al., 2013; Hinko-Najera et al., 2015; Rahmani et al., 2011; Zhang et al., 2009). Throughfall is the part of rainfall that reaches forest floor either through dripping from the tree canopies and after fulfilling initial interception storage or direct passing the canopy gaps (Chappell and Bidin, 2001; David et al., 2011; Díaz et al., 2007; Guswa and Spence, 2012; Huber and Iroumé, 2001; Rahmani et al., 2011; Roberts and Rosier, 2005; Wuyts et al., 2008; Zhang et al., 2006; Zimmermann and Zimmermann, 2014).

Many important factors viz. rainfall characteristics, canopy architecture, branch angle, canopy cover, tree age, leaves shapes, types and dimensions, phonological stages, and even silvicutural practices affect hydrologic behavior of forest stand against input rainfall (Brandt, 1987; Bruijnzeel, 2005; Davudirad et al., 2015; Davudirad et al., 2016; Gay et al., 2015; Guswa and Spence, 2012; Huber and Iroumé, 2001; Molina and Campo, 2012; Nanko et al., 2006; Onozawa et al., 2009; PérezSuárez et al., 2008; Pypker et al., 2005; Staelens et al., 2007; Van Stan et al., 2012; Xu et al., 2014). Due to dynamic varia- 
bility of affecting factors in space and time, the throughfall as an important component of hydrologic cycle in forest ecosystems (Sadeghi et al., 2008) varies temporally and spatially (Forti and Neal, 1992; Staelens et al., 2006). Previous research signified the effects of canopy gaps on spatio-temporal variability of throughfall (Forti and Neal, 1992; Keim et al., 2005; Loescher et al., 2002; Zirlewagen and von Wilpert, 2001). The importance of spatio-temporal variation in throughfall in forest ecosystems has also been reported in water balance modeling studies in forest watersheds (Zirlewagen and von Wilpert, 2001), forest lands nutrients exchange (Vernimmen et al., 2007; Zimmermann et al., 2008), soil erosion processes (Sadeghi et al., 2008) and fauna and flora studies (Xiao et al., 2000).

The Hyrcanian forest near the southern shores of the Caspian Sea of Iran and Azerbaijan (from $-25 \mathrm{~m}$ to $+10 \mathrm{~m}$ above mean sea level) is a unique ecosystem due to having a markedly different climate compared to other parts of Iran, and is very important in different ecological and hydrological aspects (Ebrahimpour et al., 2011; Rahmani et al., 2011). The location of the Caspian Sea and the Alborz Mountains mainly control the climate and the hydrology of the Hyrcanian forest. The average annual precipitation is around $1000 \mathrm{~mm}$; three times more compared to the average precipitation in Iran (Rahmani et al., 2011). Most of the tree species in the Caspian Hyrcanian Forests are deciduous means their leaves falling off at maturity or tending to fall off during cold season. Therefore, two main phenological stages of leaf-on and leaf-off can be defined. Unfortunately, the Hyrcanian plain forests are drastically threatened by human encroachment and overexploitation, despite their importance in ecological stability, and the hydrological balance.

Scrutinizing available literature showed that only a few studies have been conducted to quantitatively determine the vital role of the Hyrcanian forest on hydrological conditions. While the positive roles of Hyrcanian forest in decreasing frequency and intensity of floods and even regulating hydroclimatical conditions of the region are qualitatively known. It is necessarily needed to obtain precise estimations on hydrological components of the Hyrcanian forest to properly develop and calibrate hydrological models (Sadeghi and Mizuyama, 2007; Sadeghi et al., 2007; Sadeghi and Saeidi, 2010) in the area where the input rainfall is potentially erosive and offensive compared to other parts of Iran (Sadeghi et al., 2011). The present study has been therefore planned to investigate the spatio-temporal variations of throughfall as a main factor in rainfall partitioning in a part of the Hyrcanian plain forests. The present study aimed i) to determine the throughfall in a mixed Hyrcanian stand forest; ii) to identify the relationship between canopy cover and throuhfall and iii) to investigate the spatio-temporal variations of the throughfall in different seasons and leaf-off and leaf-on periods. The results of the present study may justify decision makers and planners to appropriately preserve the precious heritage of Hyrcanian plain forests as an important unique ecosystem in the world for the next generations due to vital services of this ecosystem in regulation of hydrological regimen of the area.

\section{MATERIAL AND METHODS Study site}

The study area has been located in the Hyrcanian plain forest at International Campus of Tarbiat Modares University at Faculty of Natural Resource in Noor City, Iran. The site was chosen due to accessibility, possibility of accurate monitoring and controlled conditions. The study site is not threatened by anthropogenic activities and therefore is representing all original
Hyrcanian plain forest situated in southern Caspian Sea shores. Average annual precipitation in the study site is $1030 \mathrm{~mm}$ according to the data (1968-2013) from the nearest meteorological (i.e, Noor Station just $2 \mathrm{~km}$ away). The study area was confined to an area of $943.25 \mathrm{~m}^{2}(38.5 \mathrm{~m} \times 24.5 \mathrm{~m})$ covered by different species viz. Carpinus betulus (55\%), Quercus castaneifolia (10\%), Parrotia persica (10\%) and Populus caspica (7\%) with respective number of trees of 35,5 , 2 and 2; also $18 \%$ is covered by grass and bare soil. The measured mean breast height diameter at the beginning of the study was measured as $26 \pm 7.5 \mathrm{~cm}$ for Quercus castaneifolia, $31 \pm 7.82 \mathrm{~cm}$ for Carpinus betulus, $104 \pm 16.5 \mathrm{~cm}$ for Populus caspica and $33 \pm 6.5 \mathrm{~cm}$ for Parrotia persica. No border effects could be recognized and therefore considered in the study, since the study area is just a small piece which has been surrounded by a similar forest stand.

\section{Sampling design}

The study was planned in a grid design of $3.5 \mathrm{~m} \times 3.5 \mathrm{~m}$ according to the canopy cover distribution and density, for which 96 throughfall collectors were installed at all corners of the squares (Lloyd, 1988; Rahmani et al., 2011). Since the measurement of throughfall in the entire selected area was concerned, the distribution pattern of the collectors was set systematically to try to mimic natural conditions where dense and sparse canopy covers, and clear areas are all together. The study design along with corresponding details has been depicted in Figure 1 . The study was carried out for all incidents ( 24 events) during one year from July 2013 to July 2014.

Gross precipitation was directly measured at the nearest open area $200 \mathrm{~m}$ from the study site to minimize the introduction of errors (Holder, 2003, 2004; Rahmani et al., 2011). Cylindrical rainwater collectors with diameters of $9 \mathrm{~cm}$ were mounted on iron rods $35 \mathrm{~cm}$ above the forest floor to measure throughfall after each rainfall event and one collector was used to measure gross precipitation. Since there was no automatic rain gage in the study area, just the depth of rainfall was recorded after each individual storm event. Since there was no automatic rain gage in the study area, just the depth of rainfall was recorded after each individual storm event. The spatial distribution of gross precipitation was assumed to be homogeneous over the small study site. The volume of the collected rainwater was determined using weighting method with the help of a portable digital scale with an accuracy of $\pm 0.1 \mathrm{~g}(\approx$ $0.017 \mathrm{~mm}$ of water in collector). The depth of the throughfall was consequently determined for each collector by dividing the volume of water by the collection area $\left(63.59 \mathrm{~cm}^{2}\right)$. All 96 throughfall collectors (Figure 1) were inspected and cleaned after each instant measurement. Some data were missed for some collectors, since they have been destructed due to passing wild animals or blowing wind. The throughfall as $\%$ of rainfall $(T F P R)$, as the principal factor of the present study, was calculated using the following equation and applying gross precipitation $(P g)$ and throughfall $(T F)$, both in $\mathrm{mm}$.

$$
T F P R=\frac{T F}{P g} \times 100
$$

The values of TFPR more than 100 indicate that the depth of throughfall was more than gross rainfall and therefore denote throughfall hotspots. In addition, the hotspots were detected using Getis Ord Hot-spot analysis in Arc GIS 10.2 at three significant levels $(\alpha=0.10,0.05$ and 0.01$)$ and using an InverseDistance spatial relationship concept (Getis and Ord, 1992). 


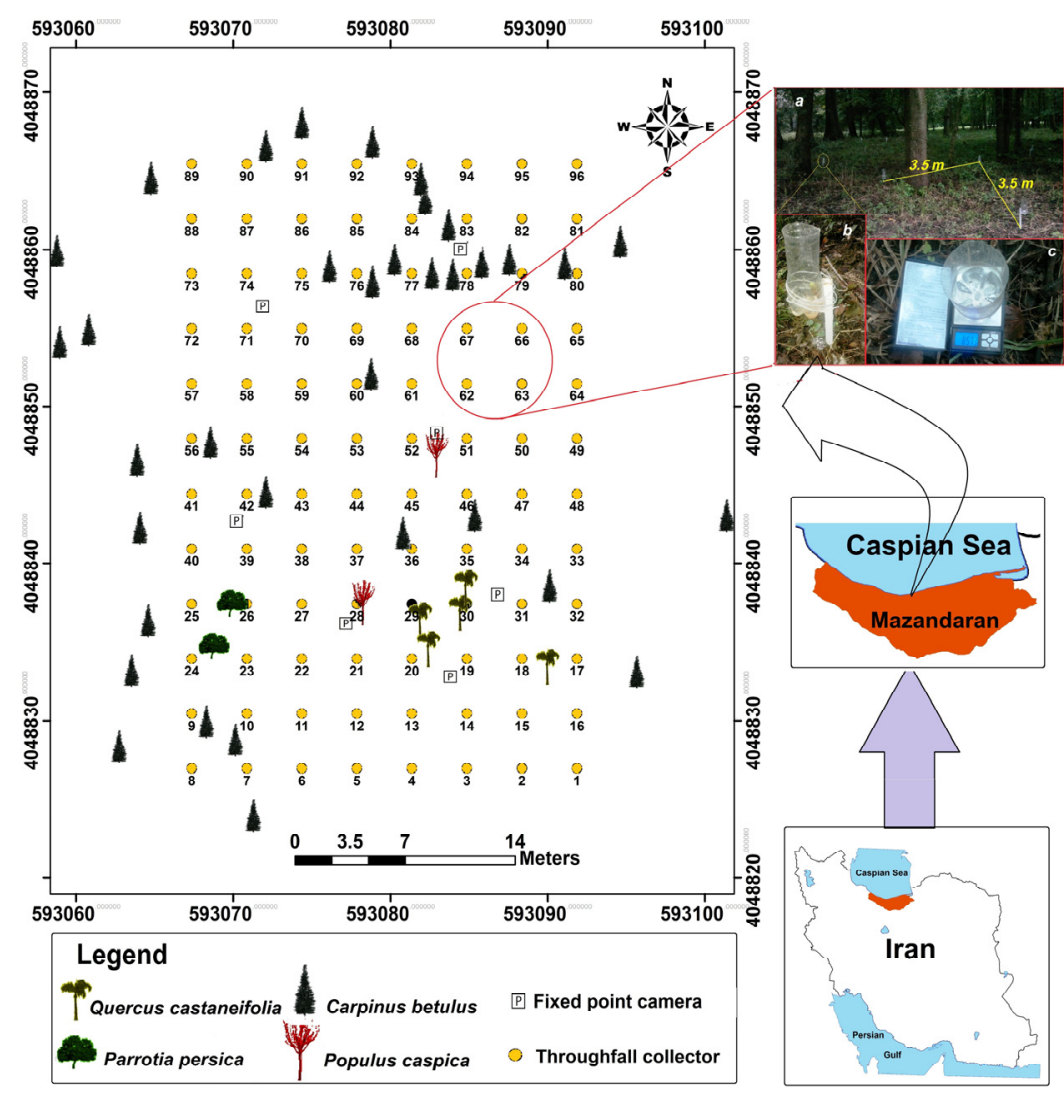

Fig. 1. General location of the study area and a ground view of the study site (a), throughfall collector (b) and weighting stage of collected throughfall (c).

Table 1. Precipitation and throughfall in a Hyrcanian forest stand during the study period.

\begin{tabular}{|c|c|c|c|c|c|c|c|c|c|c|}
\hline \multirow{2}{*}{$\begin{array}{l}\text { Temporal } \\
\text { scale }\end{array}$} & \multirow{2}{*}{ Date } & \multirow{2}{*}{$\begin{array}{l}\text { No. of } \\
\text { events }\end{array}$} & \multirow{2}{*}{$\begin{array}{l}\text { Gross precipi- } \\
\text { tation }(\mathrm{mm})\end{array}$} & \multirow{2}{*}{$\begin{array}{c}\text { No. of } \\
\text { correct } \\
\text { samples }\end{array}$} & \multirow{2}{*}{$\begin{array}{c}\text { No. of } \\
\text { hotspot } \\
\text { points }\end{array}$} & \multicolumn{4}{|c|}{ Throughfall as $\%$ of rainfall } & \multirow{2}{*}{$\begin{array}{c}\text { Canopy } \\
\text { cover }(\%)\end{array}$} \\
\hline & & & & & & Mean & Minimum & Maximum & $\begin{array}{c}\text { Standard } \\
\text { Deviation }\end{array}$ & \\
\hline \multirow{24}{*}{ Event } & 30-Jul-2013 & \multirow{24}{*}{24} & 18.95 & 64 & 10 & 73.1 & 21.2 & 160.4 & 27 & 85.0 \\
\hline & 6-Aug-2013 & & 8.81 & 94 & 12 & 75.9 & 25.6 & 165.8 & 27 & 86.0 \\
\hline & 9-Aug-2013 & & 36.17 & 94 & 0 & 58.3 & 29.5 & 118.5 & 14 & 87.5 \\
\hline & 10-Aug-2013 & & 12.38 & 95 & 0 & 46.4 & 13.7 & 89.5 & 13 & 87.5 \\
\hline & 22-Aug-2013 & & 23.18 & 94 & 2 & 59.1 & 21.2 & 116.1 & 16 & 87.8 \\
\hline & 9-Sep-2013 & & 124.65 & 90 & 2 & 55.5 & 21.5 & 112.6 & 18 & 89.6 \\
\hline & 27-Sep-2013 & & 27.94 & 92 & 9 & 74.9 & 35.4 & 114.3 & 18 & 87.0 \\
\hline & 5-Oct-2013 & & 12.58 & 92 & 2 & 54.2 & 18.3 & 157.5 & 20 & 85.0 \\
\hline & 9-Oct-2013 & & 92.32 & 93 & 2 & 62.1 & 33.0 & 136.4 & 16 & 84.0 \\
\hline & 21-Oct-2013 & & 89.33 & 64 & 7 & 82.9 & 60.0 & 230.4 & 26 & 83.5 \\
\hline & 24-Oct-2013 & & 26.01 & 91 & 3 & 67.5 & 32.8 & 139.2 & 17 & 83.0 \\
\hline & 2-Nov-2013 & & 79.45 & 71 & 6 & 72.4 & 15.2 & 248.6 & 27 & 78.0 \\
\hline & 23-Dec-2013 & & 178.66 & 42 & 1 & 68.5 & 29.2 & 112.5 & 15 & 76.0 \\
\hline & 4-Jan-2014 & & 44.82 & 90 & 3 & 62.4 & 35.4 & 134.5 & 16 & 70.0 \\
\hline & 8-Jan-2014 & & 30.53 & 88 & 8 & 70.7 & 24.6 & 169.8 & 26 & 67.5 \\
\hline & 15-Mar-2014 & & 65.27 & 84 & 12 & 79.9 & 41.9 & 172.9 & 26 & 57.8 \\
\hline & 9-Apr-2014 & & 3.33 & 89 & 2 & 47.6 & 11.6 & 105.3 & 21 & 34.1 \\
\hline & 8-May-2014 & & 4.74 & 92 & 2 & 51.6 & 19.3 & 127.1 & 21 & 68.8 \\
\hline & 4-Jun-2014 & & 8.33 & 94 & 5 & 48.8 & 5.2 & 163.8 & 32 & 83.8 \\
\hline & 22-Jun-2014 & & 23.71 & 94 & 6 & 58.5 & 17.2 & 124.4 & 17 & 84.0 \\
\hline & 4-Jul-2014 & & 11.08 & 95 & 1 & 47.8 & 15.9 & 107.0 & 22 & 84.5 \\
\hline & 8-Jul-2014 & & 4.43 & 92 & 7 & 52.4 & 18.8 & 136.1 & 21 & 85.0 \\
\hline & 14-Jul-2014 & & 5.53 & 94 & 4 & 48.9 & 15.0 & 120.4 & 20 & 85.3 \\
\hline & 21-Jul-2014 & & 6.10 & 95 & 4 & 49.7 & 20.6 & 115.0 & 21 & 86.5 \\
\hline \multirow{4}{*}{ Seasons } & Spring & 3 & 5.4 & 91 & 3 & 51.3 & 15.2 & 111.9 & 20 & 62.2 \\
\hline & Summer & 9 & 24.9 & 91 & 4 & 57.5 & 24.4 & 99.7 & 14 & 86.2 \\
\hline & Fall & 8 & 68.9 & 77 & 4 & 58.5 & 24.3 & 130.4 & 17 & 82.3 \\
\hline & Winter & 4 & 46.8 & 87 & 8 & 82.4 & 41.9 & 172.9 & 24 & 65.1 \\
\hline \multirow{2}{*}{$\begin{array}{l}\text { Growth } \\
\text { periods }\end{array}$} & Leaf-on & 19 & 44.7 & 89 & 6 & 56.6 & 18.1 & 103.9 & 15 & 83.9 \\
\hline & Leaf-off & 5 & 22.4 & 86 & 4 & 77.2 & 42.4 & 138.2 & 21 & 62.4 \\
\hline
\end{tabular}


The TFPR spatial distribution was investigated for each individual storm event using ordinary kriging method in Arc GIS 10.2 (Staelens et al., 2006) and corresponding maps were also developed in four seasons and two growth conditions. Rain events in this study were categorized in three classes of gross precipitation $<10 \mathrm{~mm}, 10-30 \mathrm{~mm}$ and $>30 \mathrm{~mm}$ as already suggested by Hosseini Ghaleh Bahmani et al. (2012).

The canopy cover of the forest stand was determined by 119 photos taken during 17 date (times) to consider intra variation of canopy cover (Sadeghi et al., 2007) at seven fixed points randomly distributed throughout the study area. The photography localities and other details have been shown in Figure 1. A Nikon Coolpix camera (20 megapixels) mounted on an wooden stack stand at $50 \mathrm{~cm}$ above the forest floor was applied to take vertical pictures to be further processed based on $\mathrm{K}$ mean classification method (Vattani, 2011) and ultimately to determine percent of canopy cover $(P C C)$.

All the statistical analyses were applied by IBM SPSS Statistics 22 software in 95\% confidence level $(\mathrm{P}<0.05)$. The influence of vegetation cover situations i.e. leaf-on and leaf-off periods on amount of TFPR and frequency of hotspot points were analyzed by paired t-test. Influence of seasonality on amount of TFPR was also analyzed by one-way ANOVA on the basis of Duncan's multiple comparison test (Rahmani et al., 2011; Ritter et al., 2005). The relation between PCC and TFPR was additionally determined by Pearson correlation test (Rahmani et al., 2011; Staelens et al., 2006).

\section{RESULTS \\ Throughfall}

A total of $938 \mathrm{~mm}$ of rain consisted of 24 events excluding a snow event was recorded between July 2013 and July 2014 (Table 1). A rare snowfall event of $120 \mathrm{~cm}$ occurred on 3 and 4 February 2014. The heavy snow covered all collectors at the study site, therefore no throughfall data were collected for this period.

The mean cumulative throughfall during the study period was $623 \pm 31 \mathrm{~mm}(\approx 66 \%$ of total rainfall $)$. The average values of throughfall as $\%$ of rainfall (TFPR) were also found $56 \pm 14 \%$ and $78 \pm 10 \%$ for leaf-on and leaf-off periods, respectively. The difference was due to changes in canopy cover of the trees in the study area during leaf-on (growing) and leaf-off (nongrowing) seasons as shown in Figure 2. The corresponding variations of mean canopy cover percentage of the study forest stand have also been presented in Figure 3.

According to the results, the average percent of canopy cover site for the entire study period was $66 \%$ varied from $41 \%$ to $81 \%$ for leaf-off and leaf-on periods, respectively. The minimum and maximum canopy covers were also recorded as $34 \%$ for 14 April 2014 and 89\% for 8 September 2013.

\section{Statistical analyses}

The relationship between gross precipitation and $T F$ both normally distributed attested by Kolmogorov-Smirnov test was considered by Pearson correlation test whose corresponding results have been summarized in Table 2 . The results showed that there was a significant correlation between $\mathrm{TF}$ and gross precipitation at $99 \%$ confidence level.

The percent of canopy cover was determined for all storm events and correlated with $T F$. The results of Pearson correlation showed that there was no significant correlation $(\mathrm{P}=0.144)$ between $P C C$ and $T F$ for gross precipitation data set $>30 \mathrm{~mm}$. However, this correlation was significant $(\mathrm{P}<0.04)$
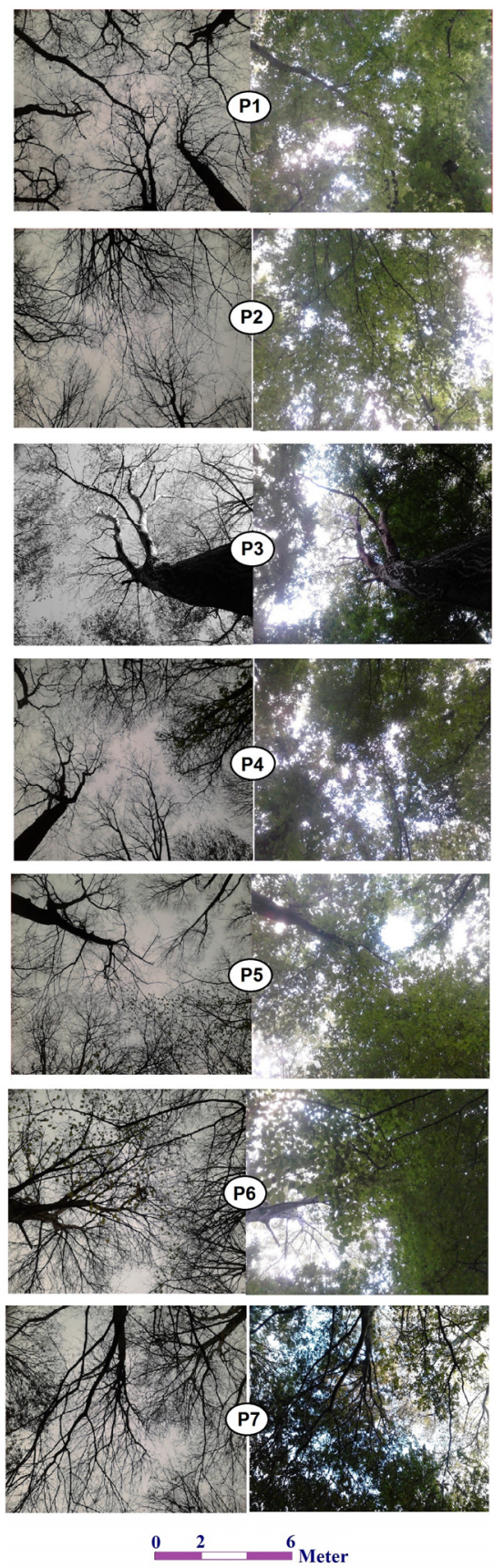

Fig. 2. Canopy pictures taken from seven photography fixed points (P1-P7) during leaf-on (right) and leaf-off (left) periods.

Table 2. Results of Pearson correlations $(p<0.001)$ among main study variables.

\begin{tabular}{|c|c|c|c|}
\hline Factor & Statistical factor & $\begin{array}{c}\text { Canopy } \\
\text { cover }(\%)\end{array}$ & $\begin{array}{l}\text { Through- } \\
\text { fall (mm) }\end{array}$ \\
\hline \multirow{3}{*}{$\begin{array}{l}\text { Gross } \\
\text { precipitation }\end{array}$} & No. of data & & \multirow{12}{*}{$\begin{array}{c}24 \\
0.987 * * \\
0.00006\end{array}$} \\
\hline & Correlation coefficient & _- & \\
\hline & Significant level & & \\
\hline \multirow{3}{*}{$\begin{array}{l}T F \text { (gross } \\
\text { precipitation }<10 \\
\mathrm{~mm})\end{array}$} & No. of data & 7 & \\
\hline & Correlation coefficient & $0.960 * *$ & \\
\hline & Significant level & 0.00004 & \\
\hline \multirow{3}{*}{$\begin{array}{l}T F(10>\text { gross } \\
\text { precipitation }<30 \\
\mathrm{~mm})\end{array}$} & No. of data & 8 & \\
\hline & Correlation coefficient & $0.882 * *$ & \\
\hline & Significant level & 0.004 & \\
\hline \multirow{3}{*}{$\begin{array}{l}\text { TF (gross precipita- } \\
\text { tion }>30 \mathrm{~mm} \text { ) }\end{array}$} & No. of data & 9 & \\
\hline & Correlation coefficient & 0.529 & \\
\hline & Significant level & 0.144 & \\
\hline
\end{tabular}

** Significant at $99 \%$ level of confidence 


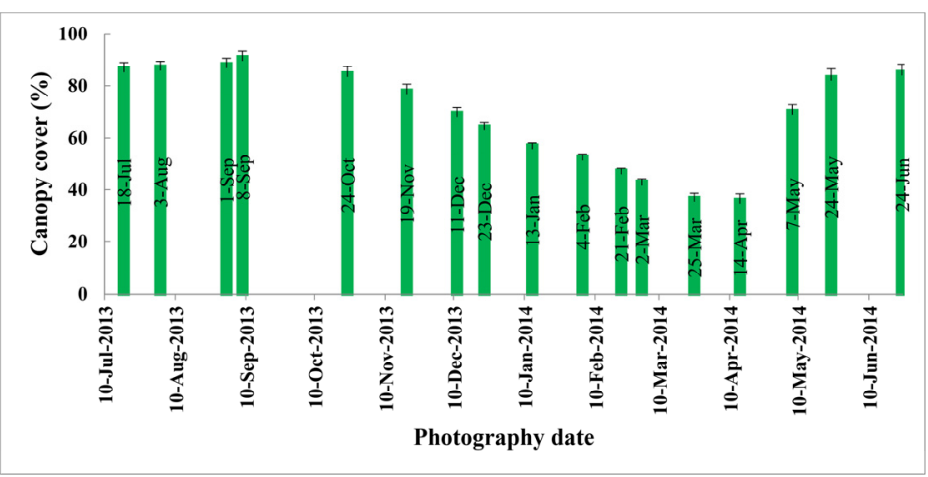

Fig. 3. Mean canopy cover variation during study period for a small Hyrcanian forest in Northern Iran.

Table 3. Results of paired t-test $(\mathrm{p}<0.001)$ in leaf-on and leaf-off conditions in view point of throughfall as $\%$ of rainfall $(T F P R)$ and hotspot frequency.

\begin{tabular}{|c|c|c|c|c|c|c|c|c|}
\hline \multirow{3}{*}{ Study variables } & \multicolumn{5}{|c|}{ Paired Differences } & \multirow{3}{*}{ t-value } & \multirow{3}{*}{$\begin{array}{l}\text { Degree of } \\
\text { freedom }\end{array}$} & \multirow{3}{*}{$\begin{array}{c}\text { Significant level } \\
\text { (2-tailed) }\end{array}$} \\
\hline & \multirow{2}{*}{ Mean } & \multirow{2}{*}{$\begin{array}{l}\text { Standard } \\
\text { deviation }\end{array}$} & \multirow{2}{*}{$\begin{array}{c}\text { Standard error } \\
\text { mean }\end{array}$} & \multicolumn{2}{|c|}{$95 \%$ Confidence interval of the difference } & & & \\
\hline & & & & Lower & Upper & & & \\
\hline$T F P R$ & 19.3 & 23.1 & 2.3 & 14.6 & 24.07 & 8.19 & 95 & 0.00005 \\
\hline Hotspot frequency & 1.87 & 2.12 & 0.38 & 1.091 & 2.65 & 4.90 & 30 & 0.00003 \\
\hline
\end{tabular}

Table 4. Results of ANOVA for comparison among $T F$ in different seasons in study forest.

\begin{tabular}{l|c|c|c|c|c}
\hline Source & $\begin{array}{c}\text { Sum of } \\
\text { squares }\end{array}$ & $\begin{array}{c}\text { Degree of } \\
\text { freedom }\end{array}$ & $\begin{array}{c}\text { Mean } \\
\text { squared }\end{array}$ & F-value & $\begin{array}{c}\text { Significant } \\
\text { level }\end{array}$ \\
\hline $\begin{array}{l}\text { Between } \\
\text { Groups }\end{array}$ & 47965.285 & 3 & 15988.4 & 41.7 & 0.0003 \\
\hline $\begin{array}{l}\text { Within } \\
\text { Groups }\end{array}$ & 145594.736 & 380 & 383.1 & & \\
\hline Total & 193560.021 & 383 & & & \\
\hline
\end{tabular}

for gross precipitation $<10 \mathrm{~mm}$ and $10-30 \mathrm{~mm}$ at $99 \%$ confidence level.

The $T F$ in two forest conditions (leaf-off and leaf-on) was also compared using paired t-test. The results showed that there was a significant difference $(\mathrm{P}<0.007)$ between lower amounts of $T F$ in leaf-off and higher amounts of $T F$ in leaf-on season at $99 \%$ confidence level. The hotspots frequency in leaf-on and leaf-off conditions was also assessed by paired t-test and reported in Table 3. The results further showed that there was a significant difference $(\mathrm{P}<0.01)$ between frequency of hotspots in leaf-on and leaf-off conditions, and the frequency of hotspots in leaf-on conditions was obviously more than those of leaf-off season.

One-way ANOVA on the basis of Duncan's multiple comparison test $(\mathrm{p}<0.05)$ was also used to compare $T F$ in different seasons whose results have been given in Table 4. Results showed that the amounts of $T F$ in different seasons had significant difference at $99 \%$ confidence level as the maximum TFPR occurred in winter $(82.36 \%)$ and the minimum TFPR was in spring $(51.29 \%)$. The results of Duncan's test also showed that there was no significant difference between TFPR in autumn $(58.49 \%)$ and summer $(57.43 \%)$ seasons.

\section{Spatio-temporal analysis of throughfall}

The spatial distribution of throughfall as \% of rainfall was mapped for the seasonal and growing/non-growing periods as shown in Figure 4. Results of spatio-temporal variations for $T F P R$ showed there were miscellaneous patterns of TFPR distribution in different seasons, especially between leaf-on and leaf-of periods.
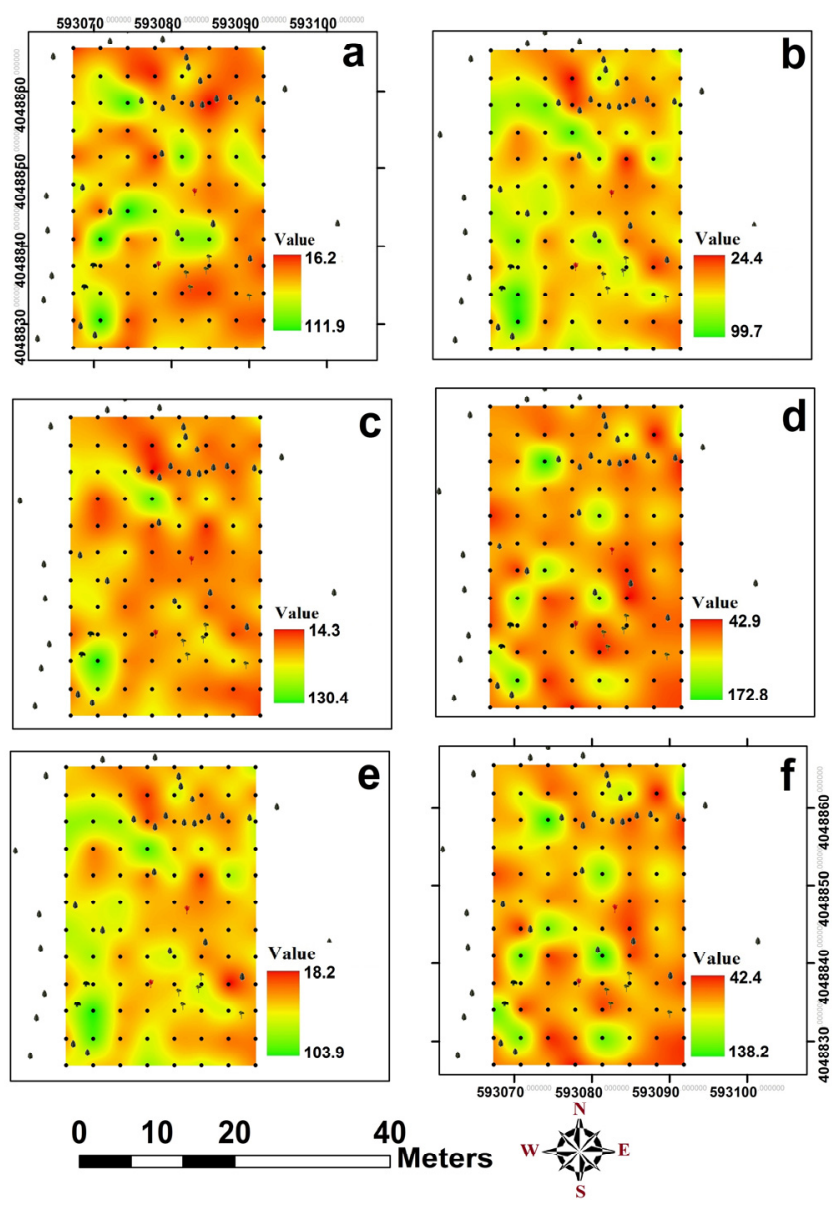

Fig. 4. Spatial variations in throughfall as \% of rainfall for spring (a), summer (b), autumn (c), winter (d), leaf-on (e) and leaf-off (f) for a representative Hyrcanian forest stand, northern Iran.

In forest floor during rainfall, TFPR in some points was more than the gross rainfall, signifying hotspots (Figure 5). These hotspots occurred through directing rainfall to spatial points by leaves and branches of trees. In addition and based on anecdotal evaluation, the hotspot frequency in collectors located 


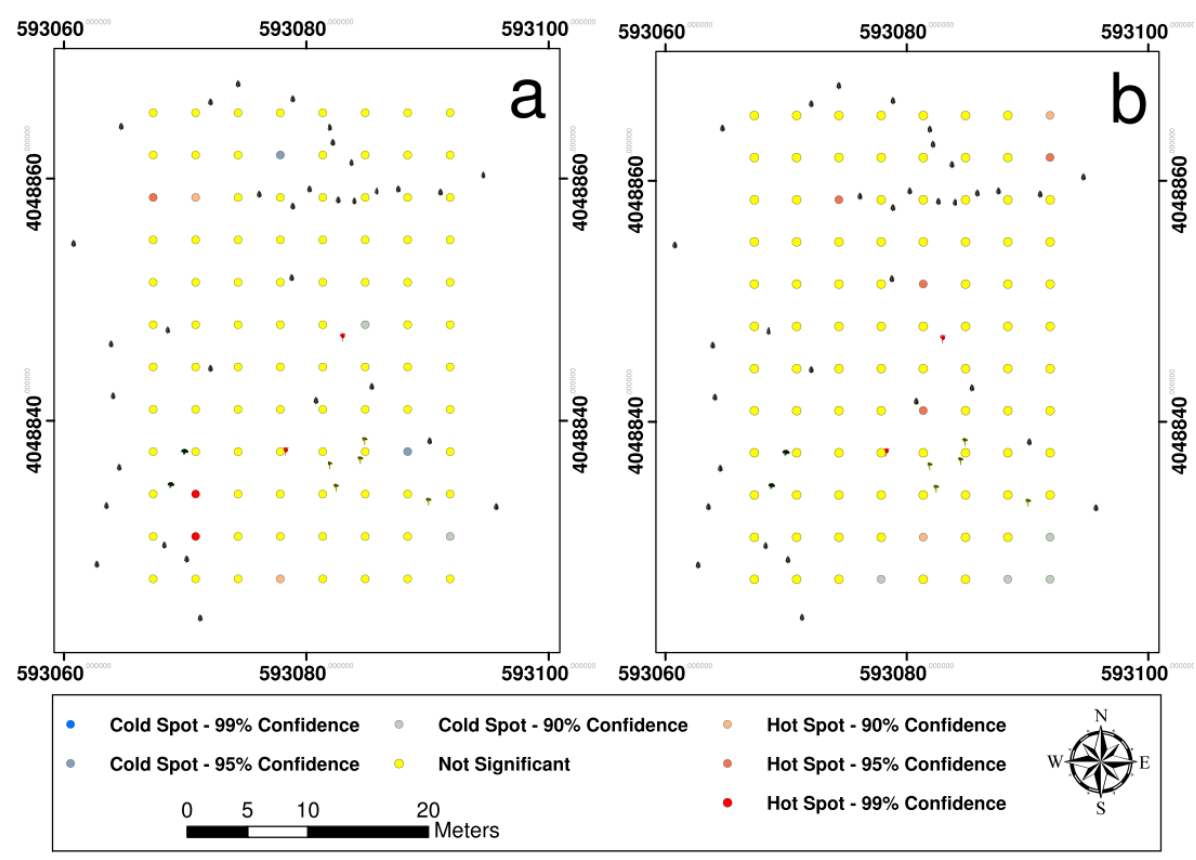

Fig. 5. Hot/cold spot analysis of TFPR for Leaf-on (a) and Leaf-off (b) periods.

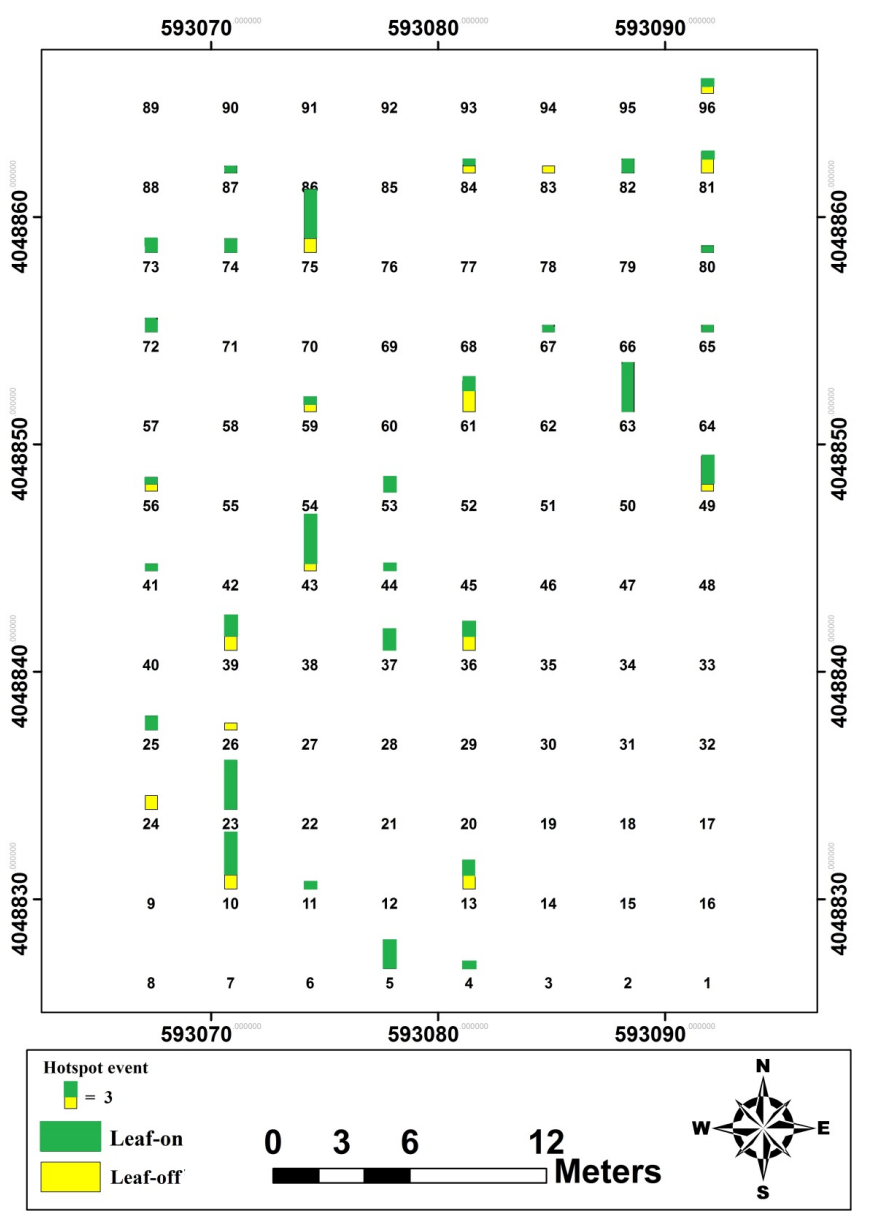

Fig. 6. Distribution of hotspot frequencies (No. of events with amounts of throughfall more than gross rainfall; the higher bar the more frequency of hotspots) during leaf-on and leaf-off periods.

in 2-6 $\mathrm{m}$ away from trees was more than collectors located closer than $2 \mathrm{~m}$ or beyond $6 \mathrm{~m}$. The hotspot frequency around the Quercus castaneifolia and Populus caspica in the both study conditions (leaf-on and leaf-off seasons) was very low. Frequency of hotspots in the study time was determined during leaf-off and leaf-on periods represented in Figure 6. 


\section{DISCUSSION}

The results of ANOVA confirmed that $T F$ in different seasons had significant difference at $99 \%$ confidence level and PRT in spring was more than other seasons. However, Duncan's classification showed that there was no significant difference between summer and fall seasons in $T F$. The graphical comparison among maps developed for seasons and growing condition of the study stand (Figure 4) verified a general symmetric condition between $T F$ distribution in summer and growing season as well as $T F$ distribution in winter and non-growing season. It clearly verified that spring and autumn played a transitional situation in two other seasons and conditions. It was also implied from the results that the Hyrcanian plain forest did not have more variation in canopy cover during summer and fall seasons. The lack of leaves in forest decreased the value of interception and increased the throughfall (Nasiri et al., 2012; Xiao et al., 2000). Besides those, the results showed that in all maps around the Parrotia persica trees, the value of $T F$ was higher than other species because of different morphologies among study species. This can be attributed to Parrotia persica having smooth leaves and branches and the frequency of grooves in this species is lower than other species leading to less interception and rain loss as reported by Nasiri et al. (2012).

The results of Pearson correlation showed that there was a significant correlation $(r=0.987)$ between $T F$ and gross precipitation. The high correlations between $T F$ and gross precipitation have already been reported by former researches (e.g., Carlyle-Moses, 2004; Gurav et al., 2012; Park and Cameron, 2008; Shachnovich et al., 2008) as 0.998, 0.988, 0.996 and 0.979 , respectively for different forest stands throughout the globe. The correlation results also showed that the influence of canopy cover to absorb the rainfall was significant just for rain events smaller than $30 \mathrm{~mm}$. This results additionally showed that the Pearson correlation coefficient for gross precipitation $<10 \mathrm{~mm}$ was more than rain events for 10 $\mathrm{mm}<$ gross precipitation $<30 \mathrm{~mm}$. The amount of interception in rainfalls with high duration and low volume was high, while it was low in events with high intensity and more volume. This is consistent with other studies (Herold et al., 2005; Hosseini Ghaleh Bahmani et al. 2012; Nasiri et al., 2012; Rahmani et al., 2011; Xiao et al., 2000). Interestingly, the throughfall values obtained for the study area as a representative area for the Hyrcanian plain were similar to the findings for mountain ecosystems in Slovakia and the Czech Republic by Holko et al. (2009) and Dohnal et al. (2014).

Results of paired sample t-test showed that there was significant difference $(P=0.007)$ between leaf-on and leaf-off periods in TFPR and hotspot frequency. Canopy cover in leaf-on period prepared conditions to reduce the amount of rain by increasing leaves and branches soak. Hotspots frequency in leaf-on period was more than leaf-off condition. Hotspots in interception system show the behavior of canopy drainage pattern (Coenders-Gerrits et al., 2013; Hopp and McDonnell, 2011). Hence, the whole branches stand downward and therefore allow easy drainage of the throughfall during leaf-on conditions. Accordingly, the hotspot frequency in collectors located in 2-6 $\mathrm{m}$ away from trees was more than other far points. This was also noticed by (Coenders-Gerrits et al., 2013; Germer et al., 2006; Ziegler et al., 2007). In addition, results showed that the hotspot frequency around the Quercus castaneifolia and Populus caspica in the both leaf-on and leaf-off periods was very low (Figure 4). The main reason for this observation was the tall growth and contact acute angel of the tributaries to the main trunk of these species as reported by Nasiri et al. (2012).
Only $66 \%$ of the annual rainfall was able to penetrate the canopy of the study forest on the study Hyrcanian plain, and the canopy spatially redistributed the precipitation reaching the forest floor. Rahmani et al. (2011), reported that an average of $43 \%$ of the total gross precipitation penetrated through the canopy as throughfall in another Hyrcanian mountain forest stand located in hilly areas (900 $\mathrm{m}$ above mean sea level). The maximum value of throughfall as \% of rainfall in the study area and during study period was $248 \%$ at collector number 23 (Figure 1) for the rain $(79.4 \mathrm{~mm})$ on 3 November 2013. The $T F$ was approximately $197 \mathrm{~mm}$ at this collector. The mean $T F$ at the study site for this rain was $23 \%$. Collector 23 was near a Parrotia persica tree. P. persica is a multi-branched tree with an earlier leaf-off period than other species. The minimum TFPR during the study was $6 \%$ at collector 85 during a rainstorm $(8 \mathrm{~mm})$ on 4 June 2014. Collector 85 was surrounded by Carpinus betulus trees. The mean TFPR for this storm was $49 \%$. C. betulus has dense foliage, and raindrops cannot easily pass directly through the crown without interacting with the foliage, especially during the growing season.

\section{CONCLUSION}

The present study figured out an approximation for throughfall rates and its variability in a Hyrcanian plain forest, northern Iran. The relevances between spatio-temporal variations of throughfall with distribution and phonological and morphological characteristics of existing species, and rainfall properties were also elucidated in the study deciduous Hyrcanian forest. Hence, the seasonal and periodical changes of throughfall were revealed at respective tunes of $49,43,42$ and $18 \%$ for spring, summer, autumn and winter. The study forest could also intercept some 43 and $23 \%$ of the rainfall in the leaf-on and leaf-off periods. The results of the present study can be effectively used by forest hydrologist to help decision makers, planner and foresters adopt appropriate silvicultural measures for better management of hydrological behavior of the Hyrcanian forest in the north of Iran. Though further insight studies with longer period and more extensive areas and even in different forest stands are essentially needed to allow drawing comprehensive conclusions.

\section{REFERENCES}

Adriaenssens, S., Hansen, K., Staelens, J., Wuyts, K., De Schrijver, A., Baeten, L., Boeckx, P., Samson, R., Verheyen, K., 2012. Throughfall deposition and canopy exchange processes along a vertical gradient within the canopy of beech (Fagus sylvatica L.) and Norway spruce (Picea abies (L.) Karst). Sci. Total Environ., 420, 168-182. DOI: 10.1016/j.scitotenv.2011.12.029.

Aikawa, M., Hiraki, T., Tamaki, M., 2006. Comparative field study on precipitation, throughfall, stemflow, fog water, and atmospheric aerosol and gases at urban and rural sites in Japan. Sci. Total Environ., 366, 1, 275-285. DOI: 10.1016/j.scitotenv.2005.06.027.

Ajami, H., Troch, P.a., Maddock, T., Meixner, T., Eastoe, C., 2011. Quantifying mountain block recharge by means of catchment-scale storage-discharge relationships. Water Resour. Res., 47, 4, 1-14. DOI: 10.1029/2010WR009598.

Bosch, J.M., Hewlett, J.D., 1982. A review of catchment experiments to determine the effect of vegetation changes on water yield and evaoptranspiration. J. Hydrol., 55, 3-23.

Brandt, J., 1987. The effect of different types of forest management on the transformation of rainfall energy by the 
canopy in relation to soil erosion. In: Proc. Vancouver Symposium Forest Hydrology and Watershed Management. IAHS Press, Wallingford, pp. 213-222.

Brecciaroli, G., Cocco, S., Agnelli, A., Courchesne, F., Corti, G., 2012. From rainfall to throughfall in a maritime vineyard. Sci. Total Environ., 438, 174-188. DOI: 10.1016/j.scitotenv.2012.08.044.

Bruijnzeel, L.A., 2005. Tropical montane cloud forest: a unique hydrological case. In: Bonell, M., Bruijnzeel, L.A. (Eds.): Forests, Water and People in the Humid Tropics: Past, Present and Future Hydrological Research for Integrated Land and Water Management. Cambridge University Press, Cambridge, UK.

Buendia, C., Batalla, R.J., Sabater, S., Palau, A., Marcé, R., 2016. Runoff trends driven by climate and afforestation in a pyrenean basin. Land Degrad. Dev., 27, 3, 823-838. DOI: 10.1002/ldr.2384.

Cao, Y., Ouyang, Z. Y., Zheng, H., Huang, Z.G., Wang, X.K., Miao, H., 2008. Effects of forest plantations on rainfall redistribution and erosion in the red soil region of Southern China, Land Degrad. Dev., 19, 3, 321-330. DOI: $10.1002 / 1 \mathrm{dr} .812$.

Carlyle-Moses, D.E., 2004. Throughfall, stemflow, and canopy interception loss fluxes in a semi-arid Sierra Madre Oriental matorral community. J. Arid. Environ., 58, 2, 181-202. DOI: 10.1016/S0140-1963(03)00125-3.

Celentano, D., Rousseau, G.X., Engel, V.L., Zelarayán, M., Oliveira, E.C., Araujo, A.C.M., de Moura, E.G., 2016. Degradation of riparian forest affects soil properties and ecosystem services provision in eastern Amazon of Brazil. Land Degrad. Dev., DOI: 10.1002/ldr.2547.

Chappell, N.A., Bidin, K., 2001. Modelling rainfall and canopy controls on net-precipitation beneath selectively-logged tropical forest. plant. Ecol., 153, 1, 215-229. DOI: 10.1023/A:1017532411978.

Coenders-Gerrits, A.M.J., Hopp, L., Savenije, H.H.G., Pfister, L., 2013. The effect of spatial throughfall patterns on soil moisture patterns at the hillslope scale. Hydrol. Earth Syst. Sci., 17, 5, 1749-1763. DOI: 10.5194/hess-17-1749-2013.

Cox, C.A., Sarangi, A., Madramootoo, C.A., 2006. Effect of land management on runoff and soil losses from two small watersheds in St Lucia. Land Degrad. Dev., 17, 1, 55-72. DOI: 10.1002/ldr.694.

David, J.S., Bellot, J., Birot, Y., David, T.S., 2011. Water fluxes in forests. In: Birot, Y., Gracia, C., Palahi, M. (Eds.): Water for Forests and People in the Mediterranean Region A Challenging Balance. What Science Can Tell Us? European Forest Institute, Sarjanr, Finland, pp. 32-36.

Davudirad, A.A., Sadeghi, S.H.R., Sadoddin, A., 2015. Monitoring temporal and spatial changes in land use in the Shazand Watershed, Iran. J. Ecohydrol., 2, 4, 405-415. (In Persian.)

Davudirad, A.A., Sadeghi, S.H.R., Sadoddin, A., 2016. The impact of development plans on hydrological changes in the Shazand Watershed, Iran. Land Degrad. Dev., 27, 4, 12361244. DOI: $10.1002 / 1 \mathrm{dr} .2523$.

Deng, Z., Priestley, S.C., Guan, H., Love, A.J., Simmons, C.T., 2013. Canopy enhanced chloride deposition in coastal South Australia and its application for the chloride mass balance method. J. Hydrol., 497, 62-70. DOI: 10.1016/j.jhydrol.2013.05.040.

Devlaeminck, R., De Schrijver, A., Hermy, M., 2005. Variation in throughfall deposition across a deciduous beech (Fagus sylvatica L.) forest edge in Flanders. Sci. Total Environ., 337, 1, 241-252. DOI: 10.1016/j.scitotenv.2004.07.005.
Díaz, M.F., Bigelow, S., Armesto, J.J., 2007. Alteration of the hydrologic cycle due to forest clearing and its consequences for rainforest succession. For. Ecol. Manage., 244, 1-3, 3240. DOI: 10.1016/j.foreco.2007.03.030.

Dohnal, M., Černý, T., Votrubová, J., Tesař, M., 2014. Rainfall interception and spatial variability of throughfall in spruce stand. J. Hydrol. Hydromech, 62, 4, 277-284. DOI: 10.2478/johh-2014-0037.

Ebrahimpour, K.J., Nemati, M., Samariha, A., 2011. Study of product of the wood in forests in North of Iran at ten years period. J. Basic. Appl. Sci. Res., 1, 9, 1255-1261.

Forti, M.C., Neal, C., 1992. Spatial variability of throughfall chemistry in a tropical rainforest (Central Amazonia, Brazil). Sci. Total Environ., 120, 3, 245-259.

Frot, E., van Wesemael, B., Vandenschrick, G., Souchez, R., Benet, A.S., 2007. Origin and type of rainfall for recharge of a karstic aquifer in the western Mediterranean: A case study from the Sierra de Gador-Campo de Dalias (southeast Spain). Hydrol. Process., 21, 3, 359-368. DOI: 10.1002/hyp.6238.

Gabarrón-Galeote, M., Martínez-Murillo, J., Quesada, M., Ruiz-Sinoga, J., 2013. Seasonal changes in the soil hydrological and erosive response depending on aspect, vegetation type and soil water repellency in different Mediterranean microenvironments. Solid. Earth., 4, 2, 497509. DOI: 10.5194/se-4-497-2013.

García-Fayos, P., Bochet, E., Cerdà, A., 2010. Seed removal susceptibility through soil erosion shapes vegetation composition. Plant. Soil., 334, 1-2, 289-297. DOI: 10.1007/s11104-010-0382-6.

Gay, T.E., Van Stan, J.T., Moore, L.D., Lewis, E.S., Reichard, J.S., 2015. Throughfall alterations by degree of Tillandsia usneoides cover in a southeastern US Quercus virginiana forest. Can. J. For. Res., 45, 12, 1688-1698. DOI: 10.1139/cjfr-2015-0233.

Germer, S., Elsenbeer, H., Moraes, J., 2006. Throughfall and temporal trends of rainfall redistribution in an open tropical rainforest, south-western Amazonia (Rondônia, Brazil). Hydrol. Earth Syst. Sci., 10, 3, 383-393. DOI: 10.5194/hess10-383-2006.

Getis, A., Ord, J.K., 1992. The analysis of spatial associataion by use of distance statistics. Geogr. Anal., 24, 189-206. DOI: 10.1111/j.1538-4632.1992.tb00261.x.

Gurav, M., D, S.K.M., Kushalappa, C.G., Vaast, P., 2012. Throughfall and interception loss in relation to different canopy levels of coffee agroforestry systems. Int. J. Environ. Sci. Technol., 1, 3. DOI: 10.1109/CHUSER.2012.6504289.

Guswa, A.J., Spence, C.M., 2012. Effect of throughfall variability on recharge: application to hemlock and deciduous forests in western Massachusetts. Ecohydrology, 5, 5, 563-574. DOI: 0.1002/eco.281.

Herold, M., Couclelis, H., Clarke, K.C., 2005. The role of spatial metrics in the analysis and modeling of urban land use change. Comput. Environ. Urban Syst., 29, 4, 369-399. DOI: $10.1016 / \mathrm{j}$.

Hinko-Najera, N., Fest, B., Livesley, S.J., Arndt, S.K., 2015. Reduced throughfall decreases autotrophic respiration, but not heterotrophic respiration in a dry temperate broadleaved evergreen forest. Agr. Forest. Meteorol., 200, 66-77. DOI: 10.1016/j.agrformet.2014.09.013.

Holder, C.D., 2003. Fog precipitation in the Sierra de las Minas biosphere reserve, Guatemala. Hydrol. Process., 17, 10, 2001-2010. DOI: 10.1002/hyp.1224.

Holder, C.D., 2004. Rainfall interception and fog precipitation in a tropical montane cloud forest of Guatemala. For. Ecol. 
Manage., 190, 2, 373-384. DOI: 10.1016/j.foreco.2003.11.004.

Holko, L., Škvarenina, J., Kostka, Z., Frič, M., Staroň, J., 2009. Impact of spruce forest on rainfall interception and seasonal snow cover evolution in the Western Tatra Mountains, Slovakia. Biologia, 64, 3, 594-599. DOI: 10.2478/s11756009-0087-6.

Hopp, L., McDonnell, J.J., 2011. Examining the role of throughfall patterns on subsurface stormflow generation. J. Hydrol., 409, 1-2, 460-471. DOI: 10.1016/j.jhydrol.2011.08.044.

Hosseini Ghaleh Bahmani, S.M., Attarod, P., Bayramzadeh, V., Ahmadi, M.T., Radmehr, A., 2012. Throughfall, stemflow, and rainfall interception in a natural pure forest of chestnutleaved oak (Quercus castaneifolia C.A. Mey.) in the Caspian forest of Iran. Ann. For. Res., 55, 2, 197-206. DOI: 10.15287/afr.2012.60.

Hosseini, M., Ghafouri, M., Tabatabaei, M.R., Ebrahimi, N.G., Zare Garizi, A., 2016. Estimation of hydrologic budget for Gharasou Watershed, Iran. Ecopersia, 4, 3, 1455-1469.

Huber, A., Iroumé, A., 2001. Variability of annual rainfall partitioning for different sites and forest covers in Chile. J. Hydrol., 248, 1-4, 78-92. DOI: 10.1016/S00221694(01)00394-8.

Keesstra, S., Bruijnzeel, L., Van Huissteden, J., 2009. Mesoscale catchment sediment budgets: combining field surveys and modeling in the Dragonja catchment, southwest Slovenia. Earth. Surf. Poc. Land., 34, 11, 1547-1561. DOI: 10.1002/esp.1846.

Keesstra, S., Kondrlova, E., Czajka, A., Seeger, M., Maroulis, J., 2012. Assessing riparian zone impacts on water and sediment movement: a new approach. Neth. J. Geosci., 91, 1-2, 245-255. DOI: 10.1016/j.cosust.2012.10.007.

Keim, R.F., Skaugset, A.E., Weiler, M., 2005. Temporal persistence of spatial patterns in throughfall. J. Hydrol., 314, 263-274. DOI: 10.1016/j.jhydrol.2005.03.021.

Lal, R., 1997. Deforestation effects on soil degradation and rehabilitation in western Nigeria. IV. Hydrology and water quality. Land Degrad. Dev., 8, 2, 95-126, DOI: 10.1002.

Llorens, P., Domingo, F., 2007. Rainfall partitioning by vegetation under Mediterranean conditions. A review of studies in Europe. J. Hydrol., 335, 1-2, 37-54. DOI: 10.1016/j.jhydrol.2006.10.032.

Lloyd, C.R., 1988. Spatial variability of throughfall and stemflow measurements in Amazonian rainforest. Agr. Forest. Meteorol., 42, 1, 63-73.

Loescher, H.W., Powers, J.S., Oberbauer, S.F., 2002. Spatial variation of throughfall volume in an old-growth tropical wet forest, Costa Rica. J. Trop. Ecol., 18, 03, 397-407. DOI: 10.1017/S0266467402002274.

Marin, C.T., Bouten, W., Sevink, J., 2000. Gross rainfall and its partitioning into throughfall, stemflow and evaporation of intercepted water in four forest ecosystems in western Amazonia. J. Hydrol., 237, 1-2, 40-57. DOI: 10.1016/S0022-1694(00)00301-2.

Mitchell, M., Robarge, W.P., Bruck, R.I., Cowling, E.B., 1986. Throughfall and Stemflow Measurements during the Summer of 1986: A Preliminary Report.

Molina, A.J., Campo, A.D., 2012. The effects of experimental thinning on throughfall and stemflow: A contribution towards hydrology-oriented silviculture in Aleppo pine plantations. For. Ecol. Manage., 269, 206-213. DOI: 10.1016/j.foreco.2011.12.037.

Nanko, K., Hotta, N., Suzuki, M., 2006. Evaluating the influence of canopy species and meteorological factors on throughfall drop size distribution. J. Hydrol., 329, 3-4, 422431. DOI: 10.1016/j.jhydrol.2006.02.036.

Nasiri, M., Zare, N., Jalilvand, H., 2012. Investigation of the effective factors on rate of stemflow for tree species in Hyrcanian forests. Egypt. J. Bio., 14, 1, 37-44. DOI: 10.4314/ejb.v14i1.4.

Novara, A., Gristina, L., Guaitoli, F., Santoro, A., Cerdà, A., 2013. Managing soil nitrate with cover crops and buffer strips in Sicilian vineyards. Solid. Earth., 4, 2, 255-262. DOI: 10.5194/se-4-255-2013, 2013.

Onozawa, Y., Chiwa, M., Komatsu, H., Otsuki, K., 2009. Rainfall interception in a moso bamboo (Phyllostachys pubescens) forest. J. For. Res., 14, 2, 111-116. DOI: 10.1007/s10310-008-0108-2.

Park, A., Cameron, J.L., 2008. The influence of canopy traits on throughfall and stemflow in five tropical trees growing in a Panamanian plantation. For. Ecol. Manage., 255, 5-6, 1915-1925. DOI: 10.1016/j.foreco.2007.12.025.

Pereira, P., Cerdà, A., Úbeda, X., Mataix-Solera, J., Martin, D., Jordán, A., Burguet, M., 2013. Spatial models for monitoring the spatio-temporal evolution of ashes after firea case study of a burnt grassland in Lithuania. Solid. Earth., 4, 1, 153-165. DOI: 10.5194/se-4-153-2013.

Pérez-Suárez, M., Fenn, M.E., Cetina-Alcala, V.M., Aldrete, A., 2008. The effects of canopy cover on throughfall and soil chemistry in two forest sites in the México City air basin. Atmosfera, 21, 1, 83-100. DOI: 10.1007/978-0-387-225203_15.

Pypker, T.G., Bond, B.J., Link, T.E., Marks, D., Unsworth, M.H., 2005. The importance of canopy structure in controlling the interception loss of rainfall: Examples from a young and an old-growth Douglas-fir forest. Agr. Forest. Meteorol., 130, 1-2, 113-129. DOI: 10.1016/j.agrformet.2005.03.003.

Rahmani, R., Sadoddin, A., Ghorbani, S., 2011. Measuring and modelling precipitation components in an Oriental beech stand of the Hyrcanian region, Iran. J. Hydrol., 404, 3, 294 303. DOI: 10.1016/j.jhydrol.2011.04.036.

Ritter, E., Dalsgaard, L., Einhorn, K.S., 2005. Light, temperature and soil moisture regimes following gap formation in a semi-natural beech-dominated forest in Denmark. For. Ecol. Manage., 206, 1, 15-33. DOI: 10.1016/j.foreco.2004.08.011.

Roberts, J., Rosier, P., 2005. The impact of broadleaved woodland on water resources in lowland UK: III. The results from Black Wood and Bridgets Farm compared with those from other woodland and grassland sites. Hydrol. Earth Syst. Sci., 9, 6, 614-620. DOI: 10.5194/hess-9-614-2005.

Sadeghi, S., Gholami, L., Sharifi, E., Khaledi Darvishan, A., Homaee, M., 2015. Scale effect on runoff and soil loss control using rice straw mulch under laboratory conditions. Solid. Earth., 6, 1, 1-8. DOI: 10.5194/se-6-1-2015.

Sadeghi, S.H.R., Mizuyama, T., Miyata, S., Gomi, T., Kosugi, K., Mizugaki, S., Onda, Y., 2007. Is MUSLE apt to small steeply reforested watershed? J. Forest Res., 12, 270-277. DOI: $10.1007 / \mathrm{s} 10310-007-0017-9$.

Sadeghi, S.H.R., Moatamednia, M., Behzadfar, M., 2011. Spatial and temporal variations in the rainfall erosivity factor in Iran. J.Agricul. Sci. Technol., 13, 451-464.

Sadeghi, S.H.R., Mizuyama, T., 2007. Applicability of Modified Universal Soil Loss Equation for prediction of sediment yield in Khanmirza watershed, Iran, Hydrol. Sci. J., 52, 5, 1068-1075. DOI:10.1623/hysj.52.5.1068.

Sadeghi, S.H.R., Mizuyama, T., Miyata, S., Gomi, T., Kosugi, K., Fukushima, T., Mizugaki, S., Onda, Y., 2008. 
Determinant factors of sediment graphs and rating loops in a reforested watershed. J. Hydrol., 356, 271-282. DOI: 10.1016/j.jhydrol.2008.04.005.

Sadeghi, S.H.R., Vangah, B.G., Safaeeian, N.A., 2007. Comparison between effects of open grazing and manual harvesting of cultivated summer rangelands of northern Iran on infiltration, runoff and sediment yield. Land. Degrad. Dev., 18, 6, 608-620. DOI: 10.1002/ldr.799.

Sadeghi, S.H.R., Saeidi, P., 2010. Reliability of sediment rating curves for a deciduous forest watershed in Iran. Hydrol.Sci. J., 55, 5, 821-831. DOI: 10.1080/02626667.2010.489797.

Shachnovich, Y., Berliner, P.R., Bar, P., 2008. Rainfall interception and spatial distribution of throughfall in a pine forest planted in an arid zone. J. Hydrol., 349, 1-2, 168-177. DOI: $10.1016 /$ j.jhydrol.2007.10.051.

Staelens, J., De Schrijver, A., Verheyen, K., 2007. Seasonal variation in throughfall and stemflow chemistry beneath a European beech (Fagus sylvatica) tree in relation to canopy phenology. Can. J. For. Res., 37, 8, 1359-1372. DOI: 10.1139/X07-003.

Staelens, J., De Schrijver, A., Verheyen, K., Verhoest, N.E.C., 2006. Spatial variability and temporal stability of throughfall water under a dominant beech (Fagus sylvatica L.) tree in relationship to canopy cover. J. Hydrol., 330, 3-4, 651-662. DOI: 10.1016/j.jhydrol.2006.04.032.

Tcherepanov, E., Zlotnik, V., Henebry, G., 2005. Using Landsat thermal imagery and GIS for identification of groundwater discharge into shallow groundwater-dominated lakes. Int. J. Remote. Sens., 26, 17, 3649-3661. DOI: 10.1080/01431160500177315.

Van Stan, J.T., Levia, D.F., Inamdar, S.P., Lepori-Bui, M., Mitchell, M.J., 2012. The effects of phenoseason and storm characteristics on throughfall solute washoff and leaching dynamics from a temperate deciduous forest canopy. Sci. Total Environ., 430, 48-58. DOI: 10.1016/j.scitotenv.2012.04.060.

Vattani, A., 2011. k-means requires exponentially many iterations even in the plane. Discrete. Comput. Geom., 45, 4, 596-616. DOI: 10.1007/s00454-011-9340-1.

Vega, J.A., Fernández, C., Fonturbel, T., 2005. Throughfall, runoff and soil erosion after prescribed burning in gorse shrubland in Galicia (NW Spain). Land Degrad. Dev., 16, 1, 37-51. DOI: 10.1002/ldr.643.

Vernimmen, R.R.E., Bruijnzeel, L.A., Romdoni, a., Proctor, J., 2007. Rainfall interception in three contrasting lowland rain forest types in Central Kalimantan, Indonesia. J. Hydrol., 340, 3-4, 217-232. DOI: 10.1016/j.jhydrol.2007.04.009.
Wuyts, K., De Schrijver, A., Staelens, J., Gielis, M., Geudens, G., Verheyen, K., 2008. Patterns of throughfall deposition along a transect in forest edges of silver birch and Corsican pine. Can. J. For. Res., 38, 3, 449-461. DOI: 0.1139/X07-181.

Xiao, Q., McPherson, E.G., Ustin, S.L., Grismer, M.E., Simpson, J.R., 2000. Winter rainfall interception by two mature open-grown trees in Davis, California. Hydrol. Process., 14, 4, 763-784. DOI: 10.1002/(SICI)10991085(200003)14:43.3.CO;2-Z.

Xu, X., Guan, H., Deng, Z., 2014. Isotopic composition of throughfall in pine plantation and native eucalyptus forest in South Australia. J. Hydrol., 514, 150-157. DOI: 10.1016/j.jhydrol.2014.03.068.

Yousefi, S., Moradi, H.R., Boll, J., Schönbrodt-Stitt, S., 2016. Effects of road construction on soil degradation and nutrient transport in Caspian Hyrcanian mixed forests. Geoderma, 284, 103-112. DOI: 10.1016/j.geoderma.2016.09.002.

Zhang, G., Zeng, G.-M., Huang, G.-H., Jiang, Y.-M., Yao, J.M., Du, C.-Y., Jiang, R., Zhang, C., 2006. Deposition pattern of precipitation and throughfall in a subtropical evergreen forest in south-central China. J. For. Res., 11, 6, 389-396. DOI: 10.1007/s10310-006-0232-9.

Zhang, Q., Xu, C.-Y., Zhang, Z., Chen, Y.D., Liu, C.-L., 2009. Spatial and temporal variability of precipitation over China, 1951-2005. Theor. Appl. Climatol., 95, 1-2, 53-68. DOI: 10.1007/s00704-007-0375-4.

Ziegler, A.D., Negishi, J.N., Sidle, R.C., Gomi, T., Noguchi, S., Nik, A.R., 2007. Persistence of road runoff generation in a logged catchment in Peninsular Malaysia. Earth. Surf. Proc. Land., 32, 13, 1947-1970. DOI: 10.1002/esp.1508.

Zimmermann, A., Zimmermann, B., 2014. Agricultural and forest meteorology requirements for throughfall monitoring: The roles of temporal scale and canopy complexity. Agr. Forest. Meteorol., 189-190, 125-139. DOI: 10.1016/j.agrformet.2014.01.014.

Zimmermann, B., Zehe, E., Hartmann, N.K., Elsenbeer, H., 2008. Analyzing spatial data: An assessment of assumptions, new methods, and uncertainty using soil hydraulic data. Water Resour. Res., 44, 10, 1-18. DOI: 10.1029/2007WR006604.

Zirlewagen, D., von Wilpert, K., 2001. Modeling water and ion fluxes in a highly structured, mixed-species stand. For. Ecol. Manage., 143, 1-3, 27-37. DOI: 10.1016/S03781127(00)00522-3.

Received 13 October 2016 Accepted 24 January 2017 